\title{
Electrosynthesized Polyaniline for the Corrosion Protection of Aluminum Alloy 2024-T3
}

\author{
Domingo Huerta-Vilca, Sandra R. Moraes and Artur J. Motheo* \\ Instituto de Química de São Carlos, Universidade de São Paulo, CP 780, 13560-970 São Carlos - SP, Brazil
}

\begin{abstract}
Filmes de polianilina aderentes a liga de alumínio 2024-T3 foram preparados por eletrodeposição a partir de soluções de ácido oxálico contendo anilina. O método mais apropriado para preparar filmes de proteção contra a corrosão foi uma deposição galvanostática sucessiva de 500 segundos. Com este tipo de filme, o potencial de circuito aberto do metal protegido deslocou de aproximadamente 0,065 V vs. ECS em comparação a liga não protegida. Coberturas de polianilina podem ser consideradas como candidatas para proteger ligas de alumínio com alto teor de cobre $(3-5 \%)$ evitando o par galvânico entre o cobre redepositado na superfície e o seio da liga. A performance dos filmes de polianilina foi verificada com testes de imersão de até 2,5 meses. O resultado observado foi bom com a formação de alguns óxidos de alumínio devido a permeação de eletrólito e assim, para otimizar a performance de coberturas protetoras estas devem conter uma camada superior isolante.
\end{abstract}

\begin{abstract}
Adherent polyaniline films on aluminum alloy 2024-T3 have been prepared by electrodeposition from aniline containing oxalic acid solution. The most appropriate method to prepare protective films was a successive galvanostatic deposition of 500 seconds. With this type of film, the open circuit potential of the coating shifted around $0.065 \mathrm{~V} v s$. SCE compared to the uncoated alloy. The polyaniline coatings can be considered as candidates to protect copper-rich $(3-5 \%)$ aluminum alloys by avoiding the galvanic couple between re-deposited copper on the surface and the bulk alloy. The performance of the polyaniline films was verified by immersion tests up to 2.5 months. It was good with formation of some aluminum oxides due to electrolyte permeation so, in order to optimize the performance a coating formulation would content an isolation topcoat.
\end{abstract}

Keywords: aluminum alloy, electrosynthesis, polyaniline, corrosion protection

\section{Introduction}

A widespread interest on polyaniline (PAni) had begun in the mid-1980s. ${ }^{1}$ PAni was synthesized by chemical and electrochemical methods, and the initial engagement was concentrated to increase the molecular weight and obviously its conductivity. ${ }^{2-6} \mathrm{~A}$ common report of the Los Alamos National Laboratory (LANL) and the National Aeronautics and Space Administration (NASA) gave the real impulse to the study of PAni as corrosion protection., ${ }^{7,8}$

Since stainless steel is intrinsically resistant to corrosion, its protection was not interesting in the begining of the 1980s. Keeping in mind that stainless steels also suffers severe corrosion by chloride (pitting corrosion), De Berry coated stainless steel with PAni in 1984, showing that doped PAni performs well as corrosion-resistant coating of AISI 430 stainless steel. ${ }^{9}$ In the following years, studies were concentrated to clarify which form of PAni is the

\footnotetext{
* e-mail: artur@iqsc.sc.usp.br
}

most protective, whether doped or undoped. The research group at Air Products and Chemicals, Inc., found that, in the absence of any topcoat, undoped PAni performed better as a corrosion-resistant coating than the doped form. . $^{10,11}$ This was determined by electrochemical impedance spectroscopy by immersion in $3 \% \mathrm{NaCl}$. Jasty et al. have also reported that undoped PAni performs better than doped PAni. ${ }^{12}$ The protective property of undoped PAni was due the formation of a thin oxide layer of $\mathrm{Fe}_{2} \mathrm{O}_{3}$ as determined by XPS-analysis. When using an overcoat of epoxy, both undoped and doped PAni showed very good performance in protecting carbon steel from corrosion.${ }^{13} \mathrm{~A}$ commercial product, Versicon ${ }^{\circledR}$, is a PAni delivered in the doped form, which can be undoped before use. Versicon ${ }^{\circledR}$, undoped and doped, dispersed in a paint has been found to be a good corrosion protection of carbon steel imparted by the iron oxides. ${ }^{14,15}$ The use of conductive polymers as additive would be fostered by their availability that they are soluble in easily handled solvents. ${ }^{16}$ Thus, the water processability of PAni is giving rise to their use as corrosion-resistant coating. ${ }^{17}$ 
Camalet et al. have electrodeposited good adherent films on carbon steel in oxalic acid solution. They detected, by XPS, measurements formation of insoluble iron (II) oxalate and other iron species on the surface. Iron(II) oxalate transformed to soluble iron (III) oxalate by anodic polarization resulting in passivation by $\mathrm{Fe}_{2} \mathrm{O}_{3}{ }^{18}$

Studies of aluminum protection by PAni have dated since mid 1990s, specially focused on the protection of high strength alloys, 2024-T3 and 7075-T6. Protection of aluminum alloy 7075 -T6 by PAni containing a polyanion has been studied in $0.5 \mathrm{~mol} \mathrm{~L}^{-1} \mathrm{NaCl} .{ }^{19}$ By comparing the corrosion protection with that of chromate, the authors concluded that doped PAni is more effective than chromate; and also more protective than the undoped form. Epstein $e t$ al. reported that sulfonated PAni and emeraldine base are effective in inhibiting corrosion of AA-2024-T3 in $0.1 \mathrm{~mol}$ $\mathrm{L}^{-1} \mathrm{NaCl}$. They also suggested that those coatings dissolve the copper containing corrosion products and thus, the galvanic pair between copper and aluminum can be eliminated and the corrosion rate reduced. ${ }^{20}$ Cogan et al. pointed out on the existence of galvanic couple between the bare alloy 2024-T3 and the PAni-coated alloy, prepared by casting a solution of emeraldine base doped with camphor sulfonic acid. ${ }^{21}$ Recently, the US Air Force became interested in the development of coatings with 30 years lifetime before maintenance. ${ }^{22}$ The increasing use of high strength aluminum alloys, especially 2024-T3 with 3 - $5 \%$ copper and 7075-T6 with $1.5 \%$ copper and $5-6 \% \mathrm{Zn}$, rises the need for protecting those materials from different types of damages caused by galvanic and pitting corrosion. From the positive performance of PAni as corrosion protection of carbon steel reported in many studies, it is possible to introduce this type of protection for aluminum and its alloys, to replace the chromate conversion coating.

A direct translation of knowledge from PAni coating on iron and steels to aluminum was not possible. This is due to the poor adherence of PAni on the aluminum surface. Further, the electrodeposition is rather difficult by two adverse effects to the polymerization process, which are the passive film growth and the hydrogen evolution reaction taking place in the potential range from -2.0 to $0.6 \mathrm{~V}$ vs. SCE. ${ }^{23}$ PAni with excellent redox properties can precisely deposit in the potential range from -0.2 to $0.6 \mathrm{~V}$ $v s$. SCE. Thus, the present work deals with the preparation of an extremely adherent film of polyaniline on aluminum alloy 2024-T3 and its corrosion resistance in $0.1 \mathrm{~mol} \mathrm{~L}^{-1}$ $\mathrm{NaCl}$. The galvanic pair between re-depositing copper and PAni is discussed in terms of galvanic current measured between electrodes of copper wire and PAni covered tungsten wire. Immersion tests in $0.1 \mathrm{~mol} \mathrm{~L}^{-1} \mathrm{NaCl}$ solution complement the study.

\section{Experimental}

Alloy samples were cut as described in the literature. ${ }^{9}$ They were embedded in acrylic resin showing a free surface area of $0.45 \mathrm{~cm}^{2}$. The surface was polished in emery paper from $320-1200$ grit, degreased in ethanol and dried at $40^{\circ} \mathrm{C}$. The surface was previously treated in $1.3 \%$ aqueous solution of alizarin for $40 \mathrm{~min}$, washed and dried at $40^{\circ} \mathrm{C}$. PAni films were deposited galvanostatically at $1 \mathrm{~mA} \mathrm{~cm}^{-2}$ and potentiostatically at $+0.750 \mathrm{~V} v s$. saturated calomel electrode (SCE). The deposition electrolyte solution was $0.12 \mathrm{~mol} \mathrm{~L}^{-1}$ aniline in $0.5 \mathrm{~mol} \mathrm{~L}^{-1} \mathrm{H}_{2} \mathrm{C}_{2} \mathrm{O}_{4}$ at $\mathrm{pH} 0.6$. Extremely adherent PAni films have been obtained, confirmed by the Sellotape test. The test consisted in attaching a special tape for testing the adherence of paints on the PAni film and peeling off by force. The freshly obtained films were submitted to electrochemical doping (at $+1.0 \mathrm{~V})$ and undoping (at $-0.2 \mathrm{~V}$ ) processes in monomerfree solution $\left(0.5 \mathrm{~mol} \mathrm{~L}^{-1} \mathrm{H}_{2} \mathrm{C}_{2} \mathrm{O}_{4}\right)$ for 5 minutes, and successively their electrochemical responses were measured. The electrodeposition, electrochemical doping/ undoping and characterization were carried out with a potentiostat / galvanostat (EG\&G PARC model 273A) controlled by the software M352 / M270 (corrosion / cyclic voltammetry). For the purpose of bi-layered films, the cyclic voltammetry technique was used, with 30 cycles, potential varying between -0.2 and $0.8 \mathrm{~V}$ and scan rate of $50 \mathrm{mV} \mathrm{s}^{-1}$. Corrosion studies were performed by potentiodynamic polarization curves in $0.1 \mathrm{~mol} \mathrm{~L}^{-1} \mathrm{NaCl}$ at $1 \mathrm{mV} \mathrm{s}^{-1}$. Weight loss measurements were performed by immersion in $0.1 \mathrm{~mol} \mathrm{~L}^{-1} \mathrm{NaCl}$ during 2.5 months. The capacity and resistance of PAni coating during immersion were simultaneously controlled by electrochemical impedance measurements performed on the same equipment attached to a frequency response analyzer (Solartron model FRA 1255). For these experiments, $a$. $c$. perturbation of $5 \mathrm{mV}$ amplitude in the frequency range 20 $\mathrm{kHz}-10 \mathrm{mHz}$ was superimposed. To measure the galvanic current between copper and PAni, copper wire and PAnicovered tungsten wire, both of equal surface area, have been used. The wire electrodes were then short-circuited by $10 \mathrm{~W}$ resistor in $0.1 \mathrm{~mol} \mathrm{~L}^{-1} \mathrm{NaCl}$ solution, the equilibrium potentials and the contact current were measured during 80 seconds.

\section{Results}

The best adherent films are those obtained after 5 successive galvanostatic depositions at $1 \mathrm{~mA} \mathrm{~cm}^{-2}$ for 500 seconds. Films deposited by 2 successive potentiostatic depositions at $+0.750 \mathrm{~V}$ for 1200 seconds 
presented similar adherence. The induction deposition period was around 50 seconds for both methods.

In Figure 1, the undoped galvanostatically prepared film does not exhibit its oxidation peak to emeraldine but the potentiostatically prepared film still shows a small peak. These electrochemical responses are similar to that of polyaniline electrodeposited on platinum in a medium with $\mathrm{pH}>3$. This similarity is very interesting because the probability of the electron transfer to occur between the aluminum alloy and the polyaniline mediated by an oxide film. ${ }^{9}$ Finally, the doping level of the galvanostatically prepared film attains much lower value than that of the potentiostatically obtained film.

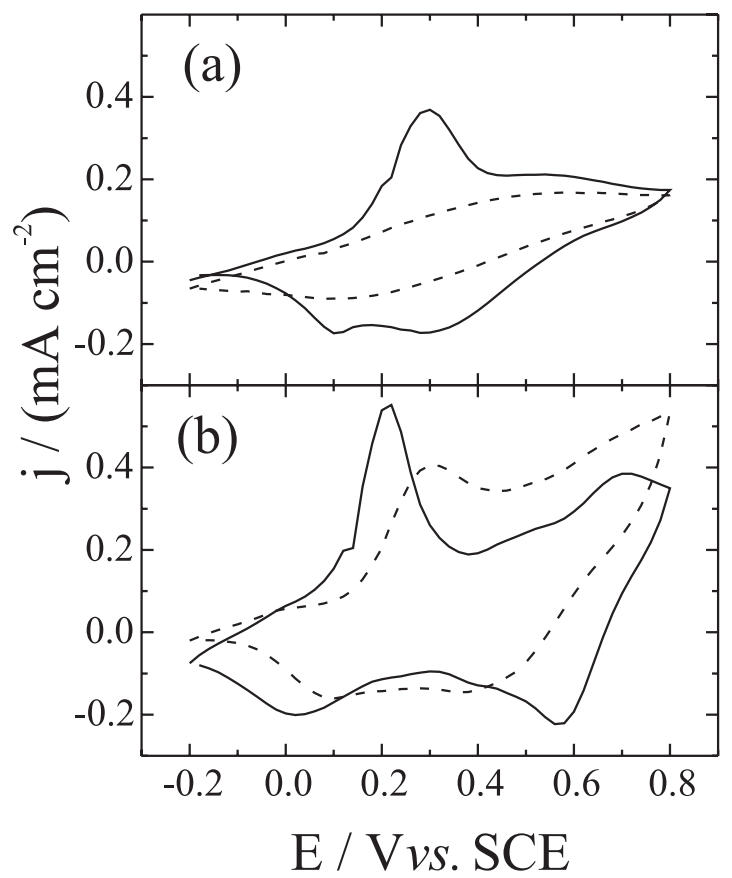

Figure 1. Electrochemical responses of PAni on AA-2024-T3 in undoped (dashed) and doped (full) condition. PAni deposition method: (a) galvanostatic and (b) potentiostatic.

The polarization curves (Figure 2) show that galvanostatically deposited PAni film is effective in protecting aluminum alloy 2024-T3 in $0.1 \mathrm{~mol} \mathrm{~L}^{-1} \mathrm{NaCl}$. The corrosion potential of the galvanostatically prepared film shifts toward anodic direction in $0.065 \mathrm{~V}$ vs. SCE compared to the bare alloy. The galvanostatically prepared film is even more protective than a bi-layered film, a film formed by cyclovoltammetric deposition onto a galvanostatically prepared film by 2 successive depositions of $500 \mathrm{~s}$ (represented as $2(500)$ ).

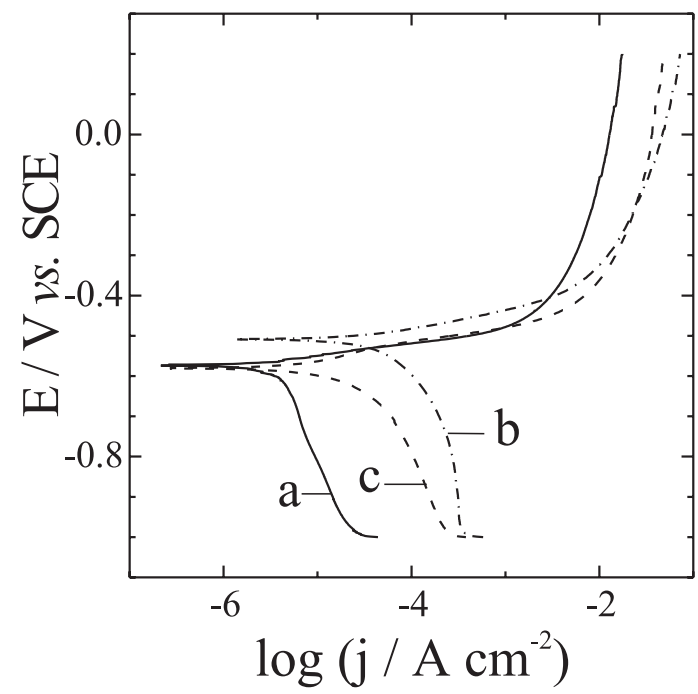

Figure 2. Polarization curves in $0.1 \mathrm{~mol} \mathrm{~L}^{-1} \mathrm{NaCl}$ for (a) AA-2024T3 bare alloy, (b) galvanostatic deposited film from $0.5 \mathrm{~mol} \mathrm{~L}^{-1}$ $\mathrm{H}_{2} \mathrm{C}_{2} \mathrm{O}_{4}$ and (c) $\mathrm{CV}$-film from $1 \mathrm{~mol} \mathrm{~L}^{-1}$ phosphate buffer solution on a $2(500 \mathrm{~s})$ galvanostatic film.

The corrosion potential, dissolution current densities and rates obtained by the polarization curves are summarized in Table 1. Thus, the observation that the corrosion current densities of coatings are higher compared to that of bare alloy could not be simply admitted. The bare alloy and the coated material are spontaneously passivate electrodes. The Tafel extrapolations works better for active dissolving electrodes. Since there were not steady-state polarization curves, the increased current densities of the coated alloy is a total current including polymer oxidation and porosity of the film, rather than the pure dissolution current of the underlying alloy surface. The corrosion rate of the galvanostatically prepared PAni coating can be considered as unrealistic because the real

Table 1. Corrosion potentials, corrosion current densities and corrosion rates, obtained from the polarization curves, for uncoated aluminum alloy 2024-T3 and coated by PAni

\begin{tabular}{lccc}
\hline Sample & $\mathrm{E}_{\text {corr }} / \mathrm{V}$ vs. SCE & $\mathrm{i}_{\text {corr }} /\left(\mathrm{A} \mathrm{cm}^{-2}\right)$ & Corrosion Rate $/\left(\mathrm{mm} \mathrm{year}^{-1}\right)$ \\
\hline $2024-\mathrm{T3}$ (bare) & -0.574 & $8.45 \times 10^{-6}$ & 0.091 \\
G-Pani $^{\mathrm{a}}+30 \mathrm{CV}$ & -0.580 & $1.36 \times 10^{-5}$ & 0.146 \\
G-Pani $^{\mathrm{a}}$ & -0.509 & $1.45 \times 10^{-4}$ & 1.558
\end{tabular}

${ }^{a}$ G-PAni: PAni deposited in the substrate by galvanostatic procedure. 
active area of the electrode is unknown and the oxidation current of PAni has a contribution from the anodic current. Therefore, a method to validate corrosion rates is the weight loss measurement.

The complementary weight loss measurements performed in $0.1 \mathrm{~mol} \mathrm{~L}^{-1} \mathrm{NaCl}$ solution during 2.5 months showed that the galvanostatic film formed by 10 depositions of $500 \mathrm{~s}$ at $1 \mathrm{~mA} \mathrm{~cm}^{-2}$, from $0.12 \mathrm{~mol} \mathrm{~L}^{-1}$ aniline and $0.5 \mathrm{~mol} \mathrm{~L}^{-1} \mathrm{H}_{2} \mathrm{C}_{2} \mathrm{O}_{4}$, did not loose any mass. After two weeks of immersion, a fair formation of crevice at the coating border was observed. On the other hand, the bare aluminum alloy 2024-T3 after $20 \mathrm{~h}$ immersion showed a selective dissolution and re-deposition of copper. This indicates that aluminum alloy 2024-T3 presents a surface with galvanic couples between aluminum and copper. To reduce the galvanic current between the two metals, PAni can be seen as a potential mediator of the galvanic corrosion.

Bode impedance spectra of galvanostatically prepared PAni coating on aluminum alloy 2024-T3 in $0.1 \mathrm{~mol} \mathrm{~L}^{-1}$ $\mathrm{NaCl}$, at open circuit potential (Voc), are exemplified in Figures 3 and 4. The spectrum of the bare alloy is also shown for comparison. Initially, high frequency impedance of $60 \Omega \mathrm{cm}^{2}$ corresponds not only to the solution resistance but some capacitance as indicated by the corresponding phase angles. The film immediately after immersion presents a capacitive behavior however, after $24 \mathrm{~h}$ immersion or longer, its characteristics turn to resistive. In contrast, the film on the bare alloy after immersion exhibits

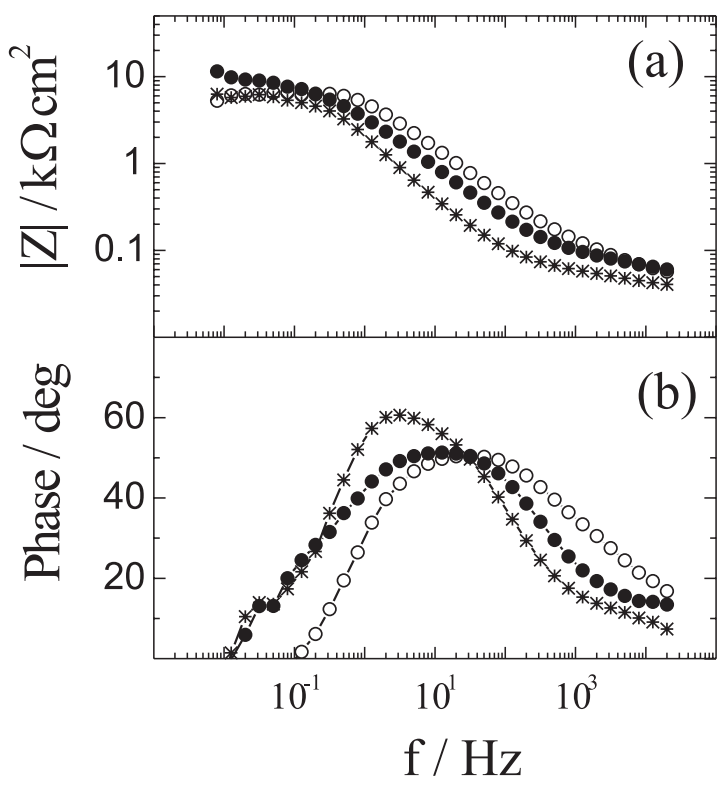

Figure 3. Bode plots of PAni-galvanostatic coating on aluminum alloy $2024-\mathrm{T} 3$ at open circuit potential $(-0.575 \mathrm{~V})$ in $0.1 \mathrm{~mol} \mathrm{~L}^{-1}$ $\mathrm{NaCl}(\mathrm{O})$ just after immersion and (๑) after $24 \mathrm{~h}$ immersion. The curves (*) correspond to the bare alloy just after immersion. lower impedance ( $40 \Omega \mathrm{cm}^{2}$ ) than the PAni film, and extends over two frequency decades. This value can be attributed mostly to solution resistance, because its phase angle tends to zero. As the phase angle does not approach $90^{\circ}$, even for the film on the bare alloy, it means that double layer charging is not the dominant electrode process. The phase angle maximum for the PAni film shifts to lower frequency from 20 to $10 \mathrm{~Hz}$ by $24 \mathrm{~h}$ immersion and to around $2 \mathrm{~Hz}$ at longer immersion. On the side of frequency lower than 0.1 $\mathrm{Hz}$, the impedance modulus increases from $6.1 \mathrm{k} \Omega \mathrm{cm}^{2}$, corresponding to the freshly prepared film, to $10 \mathrm{k} \Omega \mathrm{cm}^{2}$ after $24 \mathrm{~h}$ immersion, which is maintained until $120 \mathrm{~h}$ immersion. This can be attributed to the formation of $\mathrm{Al}_{2} \mathrm{O}_{3}$ film, which was clearly observed as a white deposit under the PAni coating after a prolonged immersion. A second time constant emerges at frequency lower than $0.1 \mathrm{~Hz}$ after immersion for $24 \mathrm{~h}$. The corresponding low frequency phase angles indicate that the impedance is low capacitive but resistive due to the $\mathrm{Al}_{2} \mathrm{O}_{3}$ formation. It is inconsistent that the film on the bare alloy also shows a second time constant at low frequency.

Figure 5 shows the mixed potential of copper wire and PAni-deposited on tungsten wire after short-circuiting in $0.1 \mathrm{~mol} \mathrm{~L}^{-1} \mathrm{NaCl}$. The equilibrium potential value of $-0.136 \mathrm{~V} v s$. SCE is attained 5 seconds after contacting the electrodes. It is observed that, in the mixed state, the

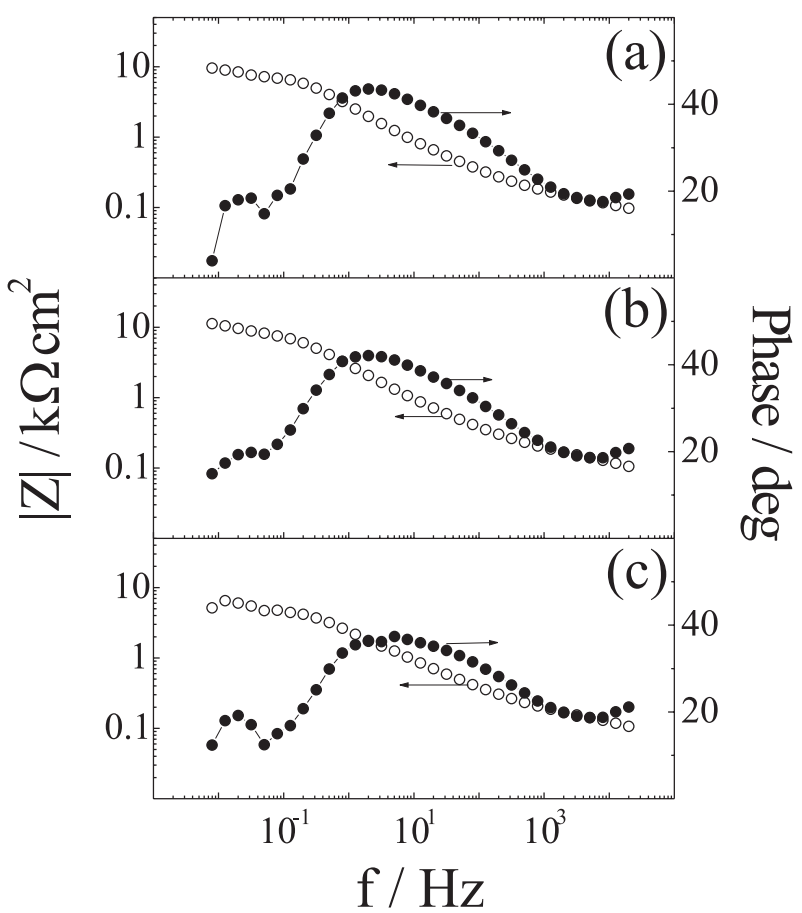

Figure 4. Bode plots of PAni-galvanostatic coating on aluminum alloy 2024-T3 at open circuit potential $(-0.575 \mathrm{~V})$ in $0.1 \mathrm{~mol} \mathrm{~L}^{-1}$ $\mathrm{NaCl}$ after (a) 72, (b) 96 and (c) $120 \mathrm{~h}$ immersion. 
electrode potential of copper prevails over that of PAni. The corresponding galvanic current during the contact of both electrodes is shown in Figure 6. At the instant of short circuiting PAni and copper, a current density of $10.55 \mu \mathrm{A}$ $\mathrm{cm}^{-2}$ flows and decreases to $1.45 \mu \mathrm{A} \mathrm{cm}^{-2}$ after 70 seconds.

Observing the polarization curves of uncoated aluminum alloy 2024-T3 and those with PAni coating in Figure 2, a galvanic contact can be seen at $-0.530 \mathrm{~V}$, between the bare alloy and the galvanostatic PAni coating, with almost $60 \mu \mathrm{A} \mathrm{cm}^{-2}$ galvanic current flowing. This current density value is six times higher than the measured current of the couple copper-PAni and it is in the same order of magnitude of that reported in the literature. ${ }^{21}$

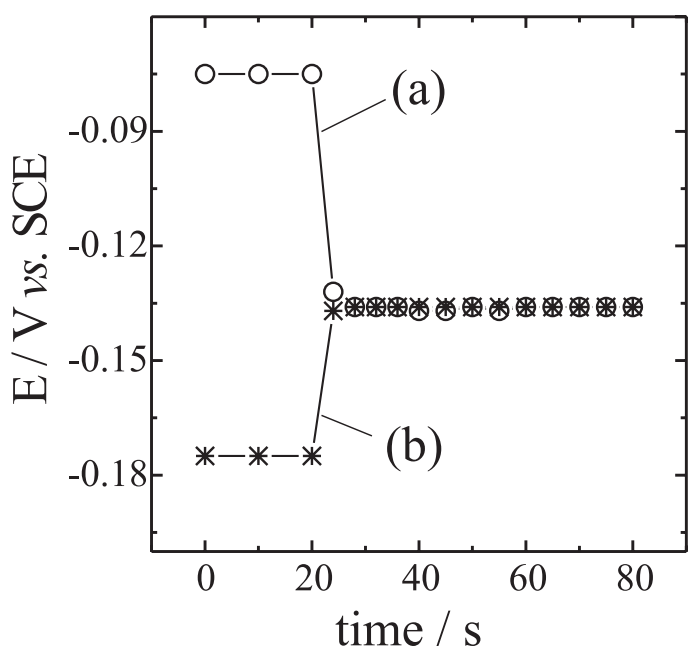

Figure 5. Changes in the potential of (a) PAni on tungsten, and (b) $\mathrm{Cu}$, during contact current measurement between copper and PAni in $0.1 \mathrm{~mol} \mathrm{~L}^{-1} \mathrm{NaCl}$.

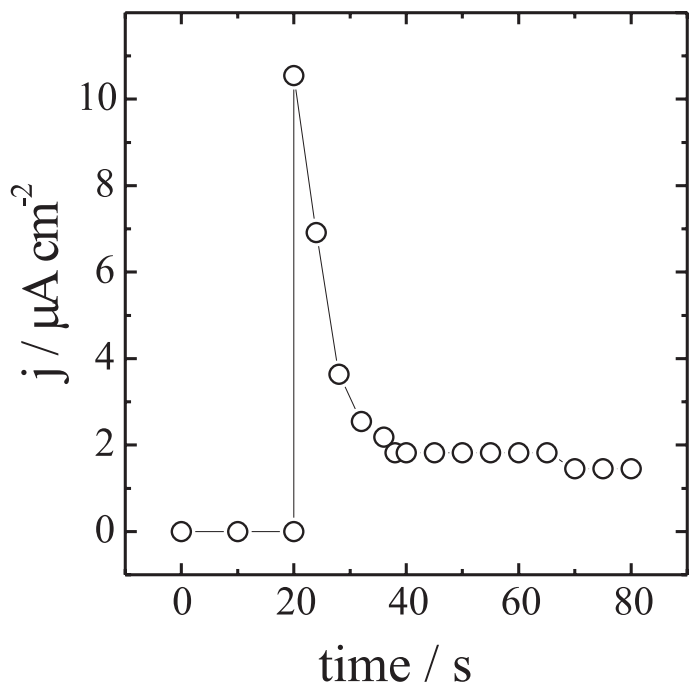

Figure 6. Contact current of the couple PAni-Cu in $0.1 \mathrm{~mol} \mathrm{~L}^{-1}$ $\mathrm{NaCl}$.

\section{Discussion}

The use of layer-by-layer galvanostatically deposited PAni on aluminum as proposed in this work has the advantage of curing the pores penetrating the substrate, which still exist in the first layers. The first of five galvanostatic deposition for 500 seconds in aniline saturated $0.5 \mathrm{~mol} \mathrm{~L}^{-1} \mathrm{H}_{2} \mathrm{C}_{2} \mathrm{O}_{4}$ solution, forms a thin conductive layer of aluminum oxalate impregnated by some nuclei of PAni. Successive galvanostatic runs are responsible for PAni film formation. An oxalate layer of good conductivity by dispersion of PAni makes possible the formation of uniform PAni layers. We are concerned with very adherent thin layers of PAni of $10-50 \mu \mathrm{m}$, whose adherence is determined by the compatibility of oxalate and PAni. When a thick porous aluminum oxide film is preferentially formed, a PAni film can not form.

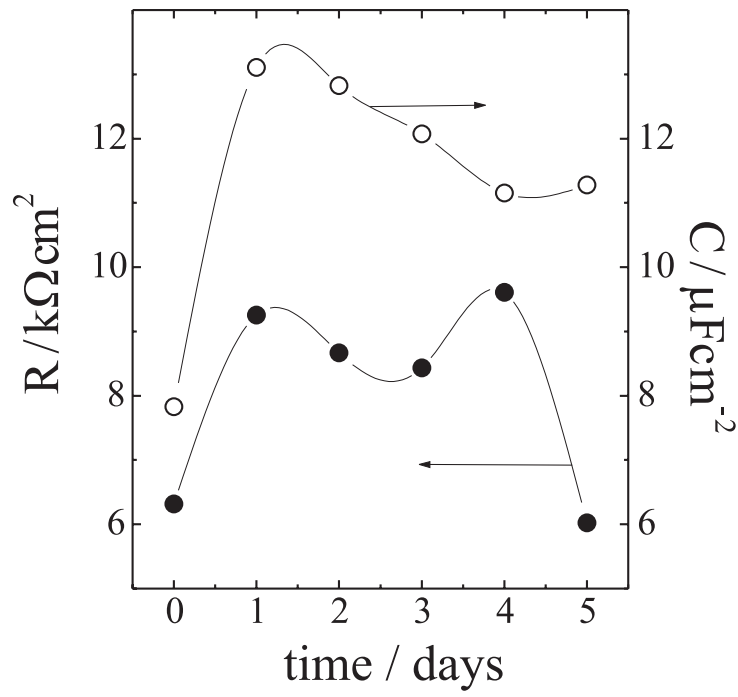

Figure 7. Film resistance (a) and capacitance (b) for PAni deposited on aluminum alloy 2024-T3 during immersion in $0.1 \mathrm{~mol} \mathrm{~L}^{-1} \mathrm{NaCl}$.

Results of the EIS-measurements in Figure 7 demonstrate that the resistance of PAni coating in contact with $0.1 \mathrm{~mol} \mathrm{~L}^{-1} \mathrm{NaCl}$ solution increases initially to decrease after longer immersion time as 5 days. The low resistance value indicates that the PAni film does not exhibit dielectric like behavior, as most of the isolation coatings acting as simple barriers, and resistance values reported elsewhere. ${ }^{24}$ Further, the PAni film was not converted to emeraldine base. The capacitance of the film increases initially to decrease slowly for immersions longer than $24 \mathrm{~h}$. On account of the slight degradation of the film, PAni can not be used alone in contact with a corroding medium. For a better corrosion performance, a topcoat of resin would be needed. It is worth 
to mention that electrochemically obtained PAni film is more uniform than the chemically prepared and solutioncast ones. The performance parameters to rank coatings, adhesion and underlayer corrosion suggested by Araujo et $a l$. , are better fulfilled in the case of electrochemical deposited films which possess good adherence. ${ }^{24}$

Figure 8 illustrates the importance of a coating to protect aluminum alloy 2024-T3. A sample of the alloy polished and immersed in $0.1 \mathrm{~mol} \mathrm{~L}^{-1} \mathrm{HCl}$ solution for 5 days presents a catastrophic corrosion (Figure 8a). On the other hand, immersing an alloy sample in a neutral solutions as $0.1 \mathrm{~mol} \mathrm{~L}^{-1} \mathrm{NaCl}(\mathrm{pH} 5.73$ ) for $12 \mathrm{~h}$, one can observe the selective dissolution of intermetallics. When the alloy is protected by a PAni film and immersed in $0.1 \mathrm{~mol} \mathrm{~L}^{-1} \mathrm{NaCl}$ solution for $12 \mathrm{~h}$, the film still remains on the top of the metallic surface with a good adherence.

\section{Conclusions}

PAni films with a very good adherence confirmed by Sellotape-Test were obtained on aluminum alloy 2024-T3 from $0.12 \mathrm{~mol} \mathrm{~L}^{-1}$ aniline in $0.5 \mathrm{~mol} \mathrm{~L}^{-1} \mathrm{H}_{2} \mathrm{C}_{2} \mathrm{O}_{4}$ by using two distinct procedures: application of five successive galvanostatic pulses of $1 \mathrm{~mA} \mathrm{~cm} \mathrm{~cm}^{-2}$ for 500 seconds each; performing two potentiostatic depositions at $0.750 \mathrm{~V}$ vs. SCE for 1,200 seconds each.

The PAni coatings, specially the galvanostatically prepared, shifts the open circuit potential of the alloy to more positive values than the bare alloy, establishing a protection potential. In particular, the PAni-coated alloy 2024-T3 does not suffer marked corrosion when immersed in $0.1 \mathrm{~mol} \mathrm{~L}^{-1} \mathrm{NaCl}$ solution for 2.5 months. Rather, a little crevice and $\mathrm{Al}_{2} \mathrm{O}_{3}$ scale can be observed after longer immersion time.

Finally, PAni coating can be considered as a good solution to the galvanic corrosion between copper and aluminum, by forming a pair with the re-depositing copper on the surface and avoiding the couple Al-Cu.

\section{Acknowledgements}

The authors thank Fundação de Amparo à Pesquisa do Estado de São Paulo (FAPESP) for the financial support (Grant numbers 99/11621-7 and 00/02674-9).

\section{References}

1. Huang, W.S.; Humphrey, B.D.; Macdiarmid, A.G.; J. Chem. Soc., Faraday Trans. I 1986, 82, 2385.

2. Manohar, S.K.; Macdiarmid, A.G.; Epstein, A.J.; Synth. Met. 1991, 41-43, 711.

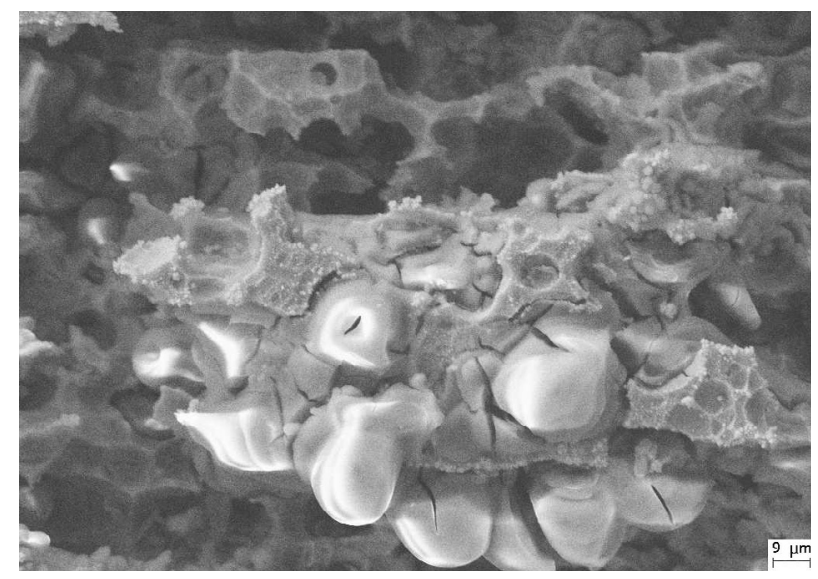

(a)

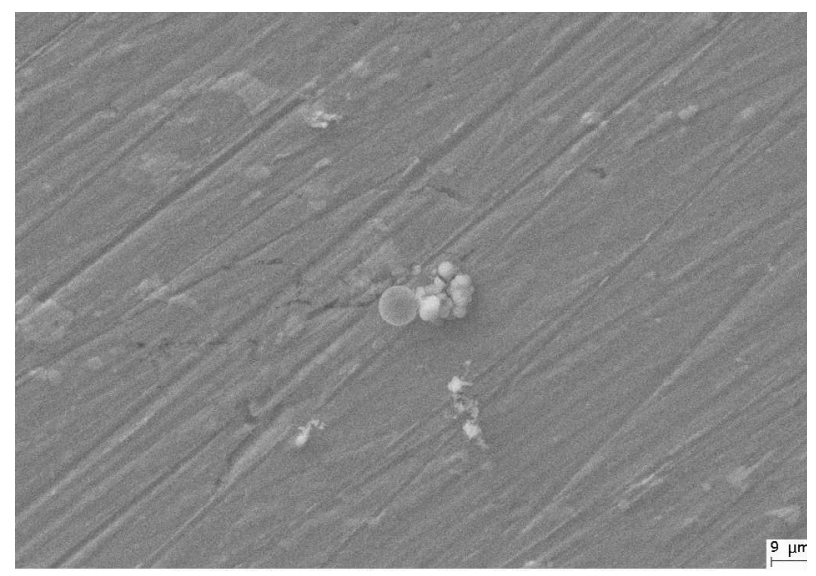

(b)

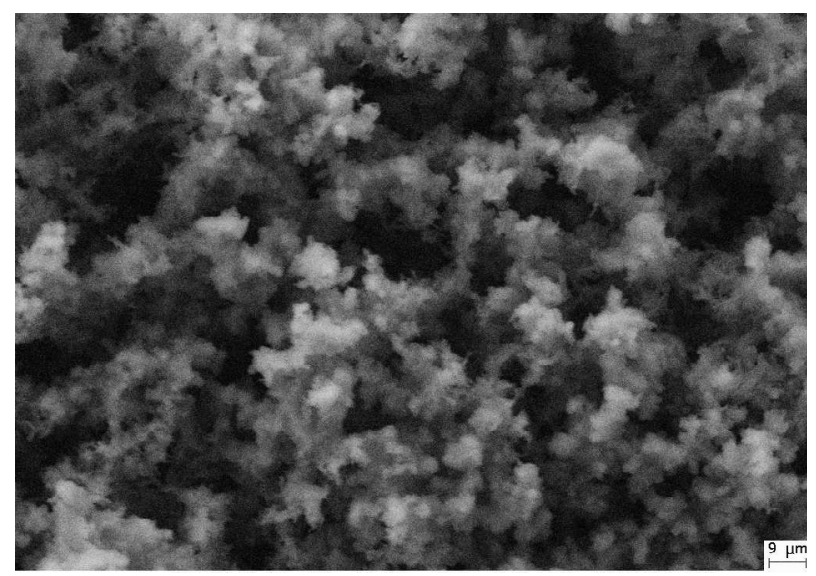

(c)

Figure 8. SEM-micrographs of AA2024-T3 alloy (a) uncovered, after 5 days immersion in $0.1 \mathrm{~mol} \mathrm{~L}^{-1} \mathrm{HCl}$, (b) uncovered, after12 h immersion in $0.1 \mathrm{~mol} \mathrm{~L}^{-1} \mathrm{NaCl}(\mathrm{pH} 5.73$ ) and (c) PAni coated alloy after $12 \mathrm{~h}$ immersion in $0.1 \mathrm{~mol} \mathrm{~L}^{-1} \mathrm{NaCl}$. 
3. Boara, G.; Spargaglioni, M.; Synth. Met. 1995, 72, 135.

4. Geniès, E.M.; Tsintavis, C.; J. Electroanal. Chem. 1986, 200, 127.

5. Triverdi, D.C. In Handbook of Organic Conductive Molecules and Polymers; Nalwa, H.S., ed., Wiley: New York, 1997, vol. 2, p. 505 .

6. Mattoso, L.H.C.; Faria, R.M.; Bulhões. L.O.S.; MacDiarmid, A.G.; Polymer 1994, 35, 5104.

7. Thompson, K.G.; Bryan, C.J.; Benicewicz, B.C.; Wroblewski, D.A.; Los Alamos National Laboratory Report LA-UR-92360, Los Alamos National Laboratory, USA, 1991.

8. Wroblewski, D.A.; Benicewicz, B.C.; Thompson, K.G.; Bryan, C.J.; Polym. Prep. Am. Chem. Soc. Div. Polym. Chem. 1994, $35,265$.

9. DeBerry, D.W.; J. Electrochem. Soc. 1985, 132, 1022.

10. McAndrew, T.P.; Miller, S.A.; Gilicinski, A.G.; Robeson, L.M.; Proc. Am. Chem. Soc., Div. Polym. Mater Sci. Eng. 1996, 74, 204.

11. McAndrew, T.P.; Gilicinski, A.G.; Robeson, L.M.; US Patent 5,441,772 1995.

12. Jasty, S.; Epstein, A.J.; Proc. Am. Chem. Soc., Div. Polym. Mater. Sci. Eng. 1995, 72, 565.

13. Lu, W.K.; Elesenbaumer, R.L.; Wessling, B.; Synth. Met. 1995, $71,2163$.
14. Wessling, B.; Adv. Mater. 1994, 6, 226.

15. Miller, G.G.; Shacklette, L.W.; Elsenbaumer, L.M.; Wessling, B.; Whang, P.; Kulkarni, V.G.; International Patent WO 93 / $14,1661993$.

16. Cao, Y.; Smith, P.; Heeger, A.J.; Synth. Met. 1992, 48, 91.

17. Santos Jr.; J.R.; Mattoso, L.H.C.; Motheo, A.J.; Electrochim. Acta 1998, 43, 309.

18. Camalet, J.L.; Lacroix, J.C.; Aeiyach, S.; Chane-Ching, K.; Lacaze, P.C.; Synth. Met. 1998, 93, 133.

19. Racicot, R.; Brown, R.; Yang, S.C.; Synth. Met. 1997, 85,1263.

20. Epstein, A.J.; Smalfield, J.A.Q.; Guan, H.; Fahlman, M.; Synth. Met. 2000, 102, 1374.

21. Cogan, S.F.; Gilbert, M.D.; Holleck, G.L.; Ehrlich, J.; Jillson, M.H.; J. Electrochem. Soc. 2000, 147, 2143.

22. Bierwagen, G.; J. Coat. Technol. 2001, 73, 45.

23. Drasic, D.M.; Popic J.P.; J. Appl. Electrochem. 1999, $29,43$.

24. Araujo, W.S.; Margarit, I.C.P.; Ferreira, M.; Mattos, O.R.; Lima Neto, P.; Electrochim. Acta 2001, 46, 1307.

Received: November 1, 2001

Published on the web: November 29, 2002

FAPESP helped in meeting the publication costs of this article. 